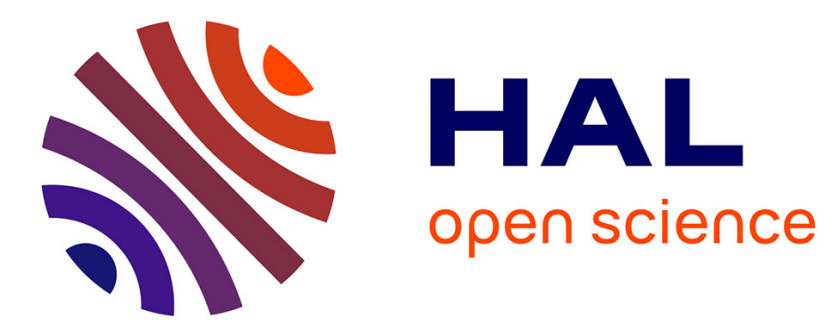

\title{
Evidence of the control of summer atmospheric transport of African dust over the Atlantic by Sahel sources from TOMS satellites (1979-2000)
}

\author{
C. Moulin, I. Chiapello
}

\section{> To cite this version:}

C. Moulin, I. Chiapello. Evidence of the control of summer atmospheric transport of African dust over the Atlantic by Sahel sources from TOMS satellites (1979-2000). Geophysical Research Letters, 2004, 31 (2), 10.1029/2003GL018931 . hal-03129904

\section{HAL Id: hal-03129904 https://hal.science/hal-03129904}

Submitted on 3 Feb 2021

HAL is a multi-disciplinary open access archive for the deposit and dissemination of scientific research documents, whether they are published or not. The documents may come from teaching and research institutions in France or abroad, or from public or private research centers.
L'archive ouverte pluridisciplinaire HAL, est destinée au dépôt et à la diffusion de documents scientifiques de niveau recherche, publiés ou non, émanant des établissements d'enseignement et de recherche français ou étrangers, des laboratoires publics ou privés. 


\title{
Evidence of the control of summer atmospheric transport of African dust over the Atlantic by Sahel sources from TOMS satellites (1979-2000)
}

\author{
C. Moulin ${ }^{1}$ and I. Chiapello ${ }^{2}$ \\ Received 27 October 2003; revised 1 December 2003; accepted 4 December 2003; published 21 January 2004.
}

[1] We used 18 years (1979-1992 and 1997-2000) of aerosol observations from TOMS satellites to monitor the inter-annual variability of summertime atmospheric dust optical thickness over both Atlantic and Africa. A comparison of TOMS dust optical thicknesses with ground-based Sun-photometer measurements shows that our long-term data set is consistent in time and space and is thus suitable for studying the interannual and decadal variability of African dust transport. Our results show that dust emissions in North western Sahel are so variable from one year to the other that they control most of the variability of summer dust transport to the tropical Atlantic. Our satellite data also demonstrate that there is a large scale correlation between Atlantic dust export and Sahel drought during the previous year, which suggests that dust emissions in this semi-arid region are likely controlled by the position of the vegetated southern boundary of the Sahara. INDEX TERMS: 0305 Atmospheric Composition and Structure: Aerosols and Particles (0345, 4801); 1640 Global Change: Remote sensing; 3322 Meteorology and Atmospheric Dynamics: Land/atmosphere interactions. Citation: Moulin, C., and I. Chiapello (2004), Evidence of the control of summer atmospheric transport of African dust over the Atlantic by Sahel sources from TOMS satellites (1979-2000), Geophys. Res. Lett., 31, L02107, doi:10.1029/2003GL018931.

\section{Introduction}

[2] Atmospheric wind-blown dust from arid regions of Africa affects the radiative budget over Africa and tropical Atlantic [Li et al., 1996; Alpert et al., 1998; Kaufman et al., 2002], likely decreases precipitations [Rosenfeld et al., 2001] and transports microbes that might significantly affect human health [Griffin et al., 2001]. Former studies based on surface measurements [Middleton, 1985; Prospero and Lamb, 2003] and satellite images [Moulin et al., 1997a; Brooks and Legrand, 2000; Chiapello and Moulin, 2002] have shown that climate variability controls the African dust export.

[3] Here we used an 18-year satellite archive to monitor summertime atmospheric dust load over both Atlantic and Africa. The semi-quantitative TOMS (Total Ozone Mapping Spectrometer) Absorbing Aerosol Index (AAI) is a unique satellite archive that provides a quasi-daily global coverage of desert dust occurrence [Herman et al., 1997]. This

\footnotetext{
${ }^{1}$ Laboratoire des Sciences du Climat et de l'Environnement, CEACNRS, Gif-sur-Yvette, France.

${ }^{2}$ Laboratoire d'Optique Atmosphérique, CNRS-USTL, Villeneuve d'Ascq, France.
}

Copyright 2004 by the American Geophysical Union. 0094-8276/04/2003GL018931\$05.00 archive has recently been used to locate major dust sources [Prospero et al., 2002] and to monitor the dust optical thickness (DOT) over ocean [Chiapello and Moulin, 2002].

\section{Data and Methods}

[4] We used 18 years of daily AAI images from the TOMS/Nimbus-7 (1979-1992) and TOMS/Earth Probe (1997-2000) sensors to compute DOT values over Africa and tropical Atlantic during the period of maximum African dust transport over the tropical Atlantic. AAI values are converted into DOT using statistical relationships estimated from a comparison of coincident daily TOMS AAI and METEOSAT DOT over the Atlantic in 1986-88 for TOMS/ Nimbus-7 [Chiapello and Moulin, 2002] and in 1997 for TOMS/Earth-Probe. Daily METEOSAT data for the period 1995-1997 were processed with the algorithm of Moulin et al. [1997b], using an updated sensor calibration [Moulin and Schneider, 1999]. The statistical relationship between METEOSAT DOT at $0.55 \mu \mathrm{m}$ and TOMS/Earth-Probe AAI for summer (April-September) is DOT $=0.45 \mathrm{AAI}-0.01$.

[5] Figure 1 compares our TOMS DOT with groundbased Sun-photometer measurements performed in Africa between 1986 and 2000. Figure 1 shows that the TOMS DOT computed using our simple relationships are in good agreement with Sun-photometer measurements, even if they are overestimated by about $8 \%$. Figure 1 also shows that TOMS/Earth-Probe tends to overestimate DOT by about $10 \%$ compared to TOMS/Nimbus-7. This difference between the two sensors has to be considered when studying long-term changes of dust transport. In contrast, DOT estimates do not show any bias between ocean (Cape Verde island) and land (Banizoumbou, Gao, Dakar) for both sensors.

[6] Daily TOMS data were then used to produce mean summer (June-August) DOT maps for the 18 available years over a region that covers western tropical Atlantic and northern Africa. For every TOMS pixels over this region, we thus have the summer DOT value for each year between 1979 and 1992 and between 1997 and 2000. This data set will be used here to quantify geographical changes in interannual variability of summer DOT and to compute pixel-bypixel the correlation between the inter-annual variability of summer DOT and that of other parameters such as the mean summer DOT integrated over the Sahel region or a Sahel drought index.

\section{Results}

[7] The summertime DOT map averaged over the 18-year TOMS archive is shown in Figure 2a. At this period 


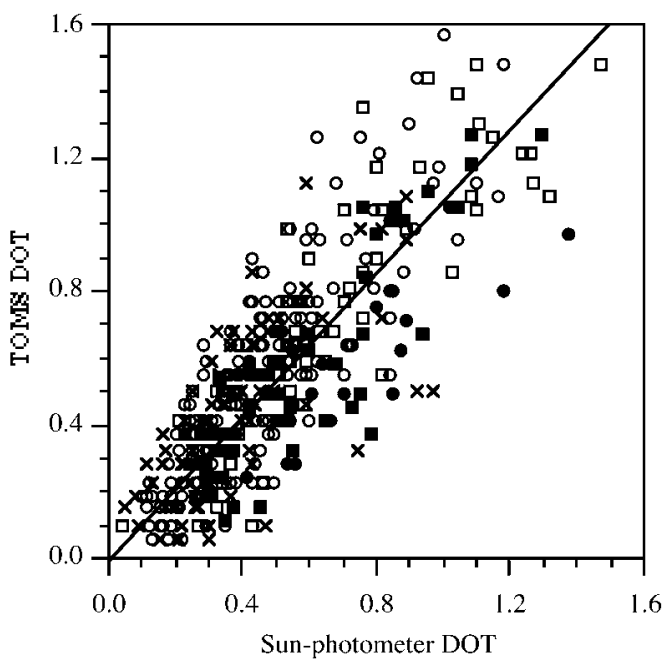

Figure 1. Comparison between TOMS and coincident Sun-Photometer DOT at $0.55 \mu \mathrm{m}$ during summer (AprilSeptember). Earth-Probe/TOMS data are compared to AERONET measurements [Holben et al., 2001] performed between 1997 and 2000 at Cape Verde Islands (O; 160 measurements), Dakar (Senegal; $\square ; 78$ measurements), and Banizoumbou (Niger; $\mathbf{x} ; 99$ measurements). Nimbus7/ TOMS DOT are compared to measurements performed during three years (1986-1988) at Gao (Mali; •; 42 measurements) [Holben et al., 1991] and during spring 1986 and 1987 at M'Bour (Senegal; $\mathbf{\square} 21$ measurements) [Tanré et al., 1988a, 1988b]. AERONET level 2.0 daily averages of optical thickness at 0.44 and $0.67 \mu \mathrm{m}$ were interpolated to derive DOT at $0.55 \mu \mathrm{m}$. At Gao, daily DOT was estimated from optical thickness measurements at $0.50 \mu \mathrm{m}$ taken at 9:00, 12:00, and 14:30 GMT. At M'Bour, daily DOT was computed from measurements made at $0.55 \mu \mathrm{m}$ with the "Proche Infrarouge Radiometer" Sun-photometer. The linear regression between TOMS and Sun-Photometer DOT for the 400 measurements gives a slope of $1.08 \pm$ 0.02 and a correlation coefficient of 0.82 . of the year, dust transport is particularly intense over the Atlantic [Moulin et al., 1997a] and is maximum between 15 and $22^{\circ} \mathrm{N}$. Major sources during summer are located in southwestern Sahara, mainly between $18^{\circ} \mathrm{N}$ and $25^{\circ} \mathrm{N}$ in Mauritania, Mali and southern Algeria [Prospero et al., 2002]. Further East, the Bodele depression (Chad) is also one of the most active African dust source [Prospero et al., 2002]. The standard deviation of DOT in Figure $2 \mathrm{~b}$ shows the high inter-annual variability of summer dust transport over western Africa and tropical Atlantic. This large-scale inter-annual variability is what makes these aerosols so difficult to account for in climate modelling because it is controlled by multiple phenomena, from the large-scale meteorology to the local weather conditions at the source.

[8] When comparing Figures $2 \mathrm{a}$ and $2 \mathrm{~b}$, it is noteworthy that the zone of maximum DOT variability widely includes the northern Sahel $\left(15-18^{\circ} \mathrm{N}\right)$ whereas the most intense sources are all located north of $18^{\circ} \mathrm{N}$. This shows that the prevailing Saharan dust sources are less variable from one year to the other than northern Sahel sources, which might thus control to the inter-annual variability of dust export to the tropical Atlantic. Figure 3 shows that the inter-annual variability of DOT over the north tropical Atlantic strongly correlates $(r>0.8)$ with that of the mean DOT averaged over northern Sahel $\left(15-17^{\circ} \mathrm{N}\right)$. This co-variation demonstrates that the variability of DOT over the Atlantic during summer is mostly due to that of Sahel dust emissions and that the intense dust flux from Sahara does not contribute much to the inter-annual variability of Atlantic transport.

[9] Inter-annual changes in dust emission over semi-arid regions can basically be due to a combination of the following three factors: a change of mean wind intensity (dynamical impact), a change of the atmospheric washout of dust particles (washout impact) and a change in soil characteristics such as humidity or vegetation coverage (drought impact). Former studies [Moulin et al., 1997a; Chiapello and Moulin, 2002] have shown that the North Atlantic Oscillation (NAO), which controls the large-scale atmospheric circulation over Atlantic, western Africa and Europe [Hurrell, 1995], has an impact on the African dust export. It has also been suggested [Middleton, 1985;
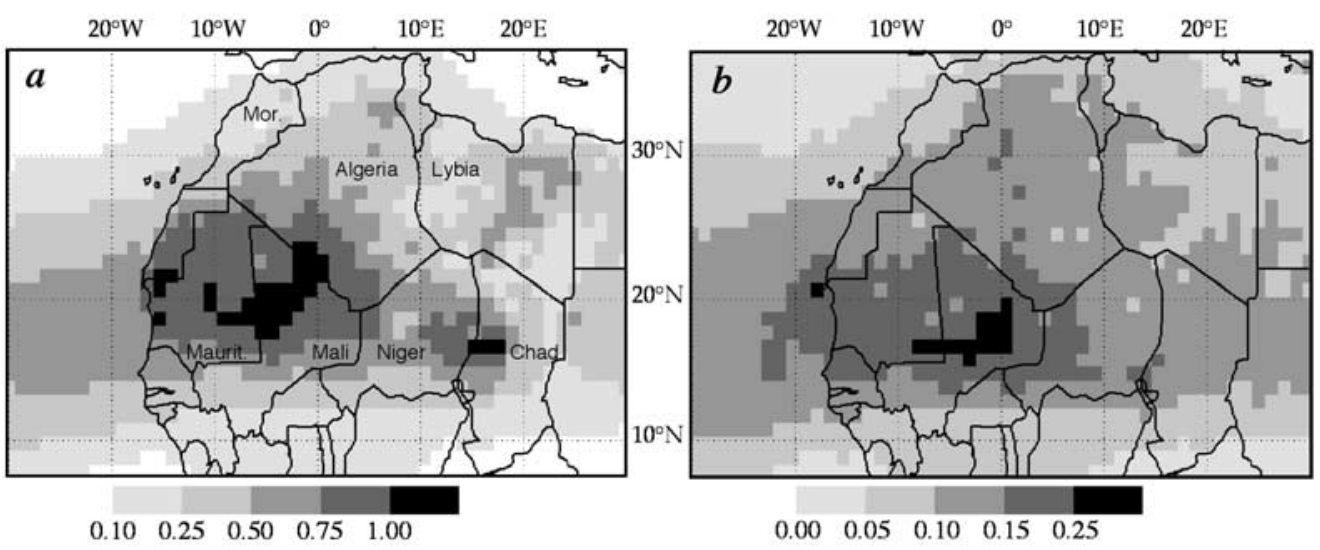

Figure 2. (a) Map of the mean summer dust optical thickness (DOT) over Africa and Atlantic computed from June to August TOMS daily images for the 18 years of daily images of the TOMS/Nimbus-7 (1979-1992) and TOMS/Earth Probe (1997-2000) sensors; (b) Map of the standard deviation of mean summer DOT over the 18 years. 


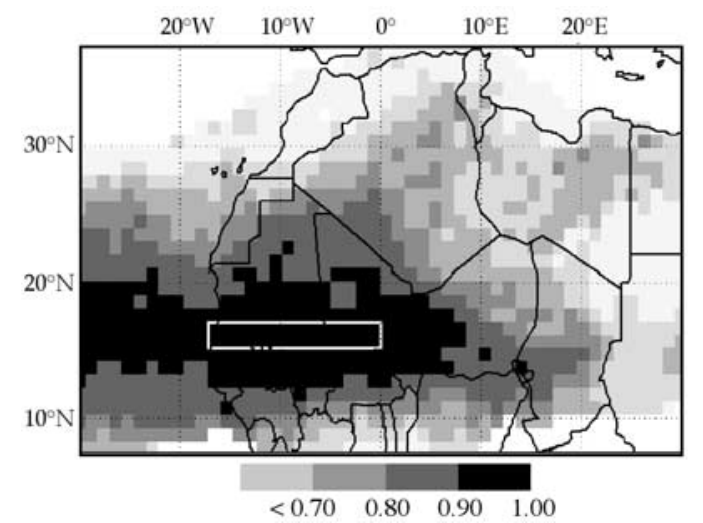

Figure 3. Correlation map between the year-to-year variability of summer DOT and that of the summer mean DOT over North western Sahel $\left(15-17^{\circ} \mathrm{N}\right.$; white rectangle). A correlation coefficient of 0.7 corresponds to a significance level of $99.9 \%$.

Prospero and Lamb, 2003] that Sahel drought controls the dust emissions.

[10] We tentatively studied the respective impact of each factor on the inter-annual variability of summer Atlantic dust export by correlating our satellite DOT to a NAO index [Hurrell, 1995], to address the dynamical impact, and to a Sahel Drought (SD) index, to evidence both rainfall and drought impacts. Our SD index is defined as the opposite of the Sahel rainfall departure index of L'Hôte et al. [2002]. Because summer is the rainy season in Sahel and because atmospheric washout is an immediate process, we used the SD index of the coincident year as a proxy for the washout impact. Drought is thought to have a more cumulative effect for example on the vegetation cover and we thus considered the SD index of the previous year to study the drought impact. Note that we verified the coherence of other available time series of both NAO [Jones et al., 1997] and Sahel rainfall departure [Nicholson et al., 2000] indices with the two indices that we selected because they fully cover our analysis period.

[11] No significant correlation was found for both NAO and same-year SD indices, suggesting that dynamical and washout impacts do not have much influence on the interannual variability of the dust emission and transport. The only exception is for the Bodele depression where correlation coefficients of $0.6-0.7$ between DOT and NAO index were locally found. In contrast, Figure 4 shows that high correlation coefficients $(r>0.5 ; p>95 \%)$ between DOT and previous-year SD index are found over both Sahel and tropical Atlantic between $12^{\circ} \mathrm{N}$ and $18^{\circ} \mathrm{N}$, which are the zones of maximum DOT variability in Figure $2 \mathrm{~b}$. This demonstrates that the drought controls Sahel dust emissions during the whole following year likely through a change in vegetation coverage, as shown from satellite observations of the Sahara extent [Nicholson et al., 1998], and that this drought is thus responsible for most of the variability in summer dust export to the tropical North Atlantic.

\section{Concluding Remarks}

[12] Figure 5 summarizes the previous result by comparing summer DOT over Sahel and tropical North Atlantic to

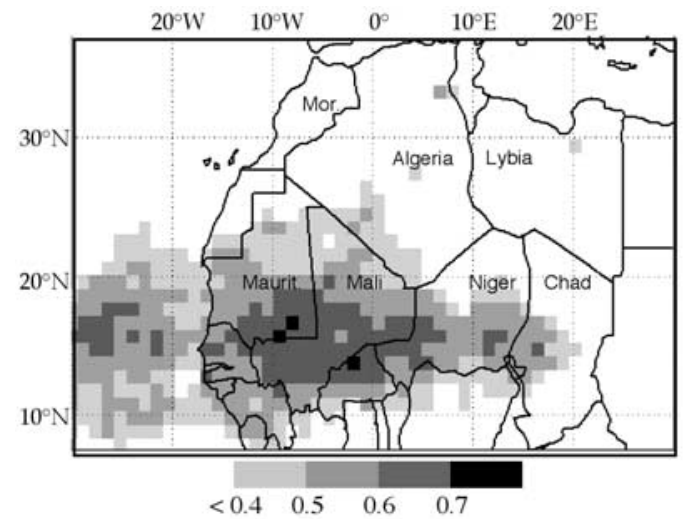

Figure 4. Map of the correlation coefficient of the year-toyear variability of the mean summer DOT with the previous-year SD index. Negative (respectively positive) SD values indicate wet (respectively dry) conditions. A correlation coefficient of 0.5 corresponds to a significance level of $95 \%$ and a correlation coefficient of 0.6 to a significance level of $99 \%$.

the SD index during the last two decades. Summer Atlantic DOT strongly varies during the two decades (0.2 to 0.5$)$ and significantly correlates with the previous-year SD index $(\mathrm{r}=$ $0.44)$, whereas no correlation $(r=0.03)$ is found with the same-year SD index. This result is however in apparent contradiction with the results of Moulin et al. [1997a] who found a correlation coefficient of 0.49 between summer Atlantic DOT and NAO index using 12 years (1983-1994) of daily METEOSAT DOT, whereas their NAO/DOT correlation for wintertime has been recently confirmed using TOMS data [Chiapello and Moulin, 2002]. This misinterpretation of the summertime dust export by Moulin et al. [1997a] comes from the significant correlation $(r=0.67)$ between NAO and previous-year SD indices during their 12-year period (1983-1994). Even if some connections are possible through the Azores High strength and position, we verified on our data set that NAO and SD are independent phenomena $(r=0.06$ over the 22 years shown in Figure 5).

[13] The correlation coefficient between Atlantic and Sahel DOT in Figure 5 is of 0.87 and is of 0.59 between

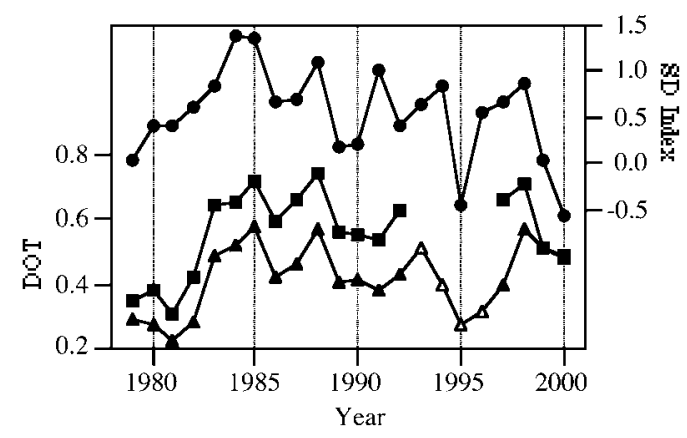

Figure 5. Inter-annual variability of summer (June to August) mean DOT over the tropical North Atlantic (17$\left.30^{\circ} \mathrm{W}, 15-30^{\circ} \mathrm{N} ; \boldsymbol{\Delta}\right)$ and Sahel $\left(17^{\circ} \mathrm{W}-10^{\circ} \mathrm{E}, 12-18^{\circ} \mathrm{N}\right.$; $\boldsymbol{\square})$, and of the previous-year Sahel Drought (SD; $\bullet$ ) index. METEOSAT daily images were used over the Atlantic to fill the gap in TOMS data between 1993 and $1996(\Delta)$. 
previous-year SD index and Sahel DOT. These results confirm the drought control on the inter-annual variability of the summer tropical Atlantic dust export. The correlation coefficient between same-year SD index and Sahel DOT is 0.17 . In contrast, this correlation coefficient remains high $(\mathrm{r}=0.40)$ for the year-2 SD index and drops down to a low value $(r=0.16)$ for the year-3 SD index. Since there is a very slight correlation between SD indices of two consecutive years $(r=0.26$ over the 22 years shown in Figure 5), this suggests that Sahel drought impacts dust sources for about two years.

[14] The 18-year TOMS record shows that dust emissions in western Sahel are extremely sensitive to drought conditions on a yearly basis and is responsible for most of the year-to-year variability in dust export over western Africa and tropical North Atlantic. Persistent drought conditions in Sahel since the early 1980s might in addition have modified more deeply the soil characteristics and generate a decadal increase of dust emission and transport. This is what suggests the increase in summer Sahel DOT twenty years apart between two low-drought periods (1979-80 and 19992000 ) in Figure 5, even if we have shown in Figure 1 that TOMS DOT are slightly overestimated over the 1997-2000 period. It is also possible that this climaterelated desertification superimposed to that due to human activities in Sahel through process like cultivation and deforestation [Sokolik and Toon, 1996], even if such an impact is still highly uncertain [Nicholson et al., 1998; Prospero et al., 2002]. Only a combination of numerical modelling [e.g., Tegen et al., 1996] with long series of satellite data and of in-situ observations will enable to separate the respective impacts of natural and anthropogenic soil degradation on Sahel dust emissions and their role in regional climate change.

[15] Acknowledgments. This work was supported by CEA and CNRS. We thank D. Tanré, P.I. of the AERONET stations used in this paper, B. Chatenet and F. Lavenu for their effort in establishing and maintaining these AERONET stations, and the Servico Nacional de Meteorologia I Geofisica at Sal Island (Cape Verde). We also thank D. Tanré, C. Devaux and B. Holben for providing the aerosol optical thickness measurements at M'Bour (Senegal) and Gao (Mali).

\section{References}

Alpert, P., Y. J. Kaufman, Y. Shay-El, D. Tanré, A. Da Silva, S. Schubert, and Y. H. Joseph (1998), Quantification of dust-forced heating of the lower troposphere, Nature, 395, 367-370.

Brooks, N., and M. Legrand (2000), Dust variability over northern Africa and rainfall in the Sahel, in Linking Climate Change to Land Surface Change, edited by S. J. McLaren and D. R. Kniveton, pp. 1-25, Kluwer Academic Publishers, New York.

Chiapello, I., and C. Moulin (2002), TOMS and METEOSAT satellite records of the variability of Saharan dust transport over the Atlantic during the last two decades (1979-1997), Geophys. Res. Lett., 29(8), $17-20$.

Griffin, D. W., V. H. Garrison, J. R. Herman, and E. A. Shinn (2001), African desert dust in the Caribbean atmosphere: Microbiology and public health, Aerobiologia, 17, 203-213.
Herman, J. R., P. K. Bhartia, O. Torres, C. Hsu, C. Seftor, and E. Celarier (1997), Global distribution of UV-absorbing aerosols from Nimbus 7/ TOMS data, J. Geophys. Res., 102(D14), 16,911-16,922.

Holben, B. N., T. F. Eck, and R. S. Fraser (1991), Temporal and spatial variability of aerosol optical depth in the Sahel region in relation to vegetation remote sensing, J. Int. Remote Sensing, 12, 1147-1163.

Holben, B. N., D. Tanré, A. Smirniv, T. F. Eck, I. Slutsker, N. Abuhassan, W. W. Newcomb, J. S. Schafer, B. Chatenet, F. Lavenu, Y. J. Kaufman, J. Vande Castle, A. Setzer, B. Markham, D. Clark, R. Frouin, R. Halthore, A. Karneli, N. T. O’Neill, C. Pietras, R. T. Pinker, K. Voss, and G. Zibordi (2001), An emerging ground-based aerosol climatology: Aerosol optical depth from AERONET, J. Geophys. Res., 106(D11), 12,067$12,097$.

Hurrell, J. W. (1995), Decadal trend in the North Atlantic Oscillation: Regional temperatures and precipitations, Science, 269, 676-679.

Jones, P. D., T. Jonsson, and D. Wheeler (1997), Extension to the North Atlantic Oscillation using early instrumental pressure observations from Gibraltar and South-West Iceland, J. Int. Climatol., 17, 1433-1450.

Kaufman, Y. J., D. Tanré, and O. Boucher (2002), A satellite view of aerosols in the climate system, Nature, 419, 215-223.

L'Hôte, Y., G. Mahé, B. Somé, and J. P. Triboulet (2002), Analysis of a Sahelian annual rainfall index from 1896 to 2000; the drought continues, Hydrol. Sci., 47, 563-572.

Li, X., H. Maring, D. Savoie, K. Voss, and J. M. Prospero (1996), Dominance of mineral dust in aerosol light scattering in the North Atlantic Trade Winds, Nature, 380, 416-419.

Middleton, N. J. (1985), Effect of drought on dust production in the Sahel, Nature, 316, 431-434.

Moulin, C., and X. Schneider (1999), Calibration of the Meteosat-5 sensor visible channel, J. Int. Remote Sens., 20, 195-200.

Moulin, C., C. E. Lambert, F. Dulac, and U. Dayan (1997a), Control of atmospheric export of dust from North Africa by the North Atlantic Oscillation, Nature, 387, 691-694.

Moulin, C., F. Guillard, F. Dulac, and C. E. Lambert (1997b), Long-term daily monitoring of Saharan dust load over ocean using Meteosat ISCCPB2 data, 1, Methodology and preliminary results for 1983-1994 in the Mediterranean, J. Geophys. Res., 102(D14), 16,947-16,958.

Nicholson, S. E., C. J. Tucker, and M. B. Ba (1998), Desertification, drought and surface vegetation: An example from the West African Sahel, Bull. Am. Meteorol. Soc., 79, 815-829.

Nicholson, S. E., B. Somé, and B. Koné (2000), An analysis of recent rainfall conditions in West Africa, including the rainy seasons of the 1997 El Niño and the 1998 La Niña years, J. Clim., 13, 2628-2640.

Prospero, J. M., and P. J. Lamb (2003), African droughts and dust transport to the Caribbean: Climate change implications, Science, 302, 10241027.

Prospero, J. M., P. Ginoux, O. Torres, S. Nicholson, and T. Gill (2002), Environmental characterization of global sources of atmospheric soil dust identified with the NIMBUS 7 Total Ozone Mapping Spectrometer (TOMS) absorbing aerosol product, Rev. Geophys., 40, 1-31.

Rosenfeld, D., Y. Rudich, and R. Lahav (2001), Desert dust suppressing precipitation: A possible desertification feedback loop, Proc. Natl. Acad. Sci., 98, 5975-5980.

Sokolik, I. N., and O. B. Toon (1996), Direct radiative forcing by anthropogenic airborne mineral aerosols, Nature, 381, 681-683.

Tanré, D., C. Devaux, M. Herman, and R. Santer (1988a), Radiative properties of desert aerosols by optical ground-based measurements at solar wavelengths, J. Geophys. Res., 93(D11), 14,223-14,231.

Tanré, D., P. Y. Deschamps, C. Devaux, and M. Herman (1988b), Estimation of saharan aerosol optical thickness from blurring effects in thematic mapper data, J. Geophys. Res., 93(D12), 15,955-15,964.

Tegen, I., A. A. Lacis, and I. Fung (1996), The influence on climate forcing of mineral aerosols from disturbed soils, Nature, 380, 419-422.

C. Moulin, Laboratoire des Sciences du Climat et de 1'Environnement, CEA-CNRS, 91191, Gif-sur-Yvette, France. (moulin@1sce.saclay.cea.fr)

I. Chiapello, Laboratoire d'Optique Atmosphérique, CNRS-USTL, 59655, Villeneuve d'Ascq, France. 